\section{EREM 76/4}

Journal of Environmental Research, Engineering and Management

Vol. 76 / No. 4 / 2020

pp. $76-86$

DOI 10.5755/j01.erem.76.4.24689
Desulphurization Efficiency of Snail Shell on Coal-Groundnut Shell Briquette
Accepted after revision 2020/08
Received 2019/11

\title{
Desulphurization Efficiency of Snail Shell on Coal-Groundnut Shell Briquette
}

\author{
Olatunde A. Oyelaran*, Olawale M. Sanusi, Tunde O. Ogundana, Bukola O. Bolaji \\ Department of Mechanical Engineering, Federal University Oye-Ekiti, Nigeria
}

Adefunke A. Odetoye

Department of Crop Science and Horticulture, Federal University Oye-Ekiti, Nigeria

*Corresponding author: ajanioyelaran@gmail.com

The diminishing accessibility of wood fuel and the danger of desertification and deforestation call for interest in the use of alternative energy sources. Herein, we studied the properties of bio-briquettes produced from Onyeama coal in Nigeria and groundnut shell used as the desulphurizer, while cassava starch was used as binder with Snail shell. For effective capturing of Sox, snail shell was added. The ratios of coal to groundnut shell $(w / w)$ in the briquette were 90:10, 80:20, 70:30, 60:40 and 50:50, while 1:1, 1.25:1, 1.5:1, 1.75:1 and 2:1 were used as the ratios of calcium to sulphur (Ca/S) in mole/mole. The briquette was then subjected to some physical characteristics and desulphurization was carried out between 300 to $500^{\circ} \mathrm{C}$ at an interval of $50^{\circ} \mathrm{C}$ at an airflow rate of $1.2 \mathrm{~L} / \mathrm{min}$ for 12 minutes. The results illustrated that $88.1 \%$ was the highest desulphurization efficiency with $2: 1 \mathrm{Ca} / \mathrm{S}$ ratio at $500^{\circ} \mathrm{C}$. The results showed that the durability ranged between 88.67 and 98.67 , the porosity index ranged between 0.19 to 0.41 , while the humidity resistance ranged between 95.15 and $99.15 \%$. The best briquette in terms of durability and relative humidity resistance is briquette made of $90 \%$ coal with a $\mathrm{Ca} / \mathrm{S}$ 1:1 desulphurizer ratio, which is preferred for household and cottage industrial applications. However, the use of a Ca/S desulphurizer in the ratio of $\mathrm{Ca} / \mathrm{S} 2: 1$ at 500 gave better desulphurization. The introduction of $\mathrm{SO}_{2}$ adsorbent also reduced the $\mathrm{SOx}$ emitted to the atmosphere.

Keywords: desulphurizer, snail shell, coal, durability, efficiency. 


\section{Introduction}

Biomass, the principal agricultural residues, shows the potential to be one of the optimistic energy sources for developing countries (Patomsok, 2008). The major sources of renewable energy in Nigeria are wood in the form of wood fuel and charcoal, representing about 51\% of the annual total energy consumption (Oyelaran et al., 2015a). Natural gas (5.2\%), hydroelectricity (3.1\%), and petroleum products (41.3\%) represent the other sources of energy (Bolaji, 2005; Oyelaran et al., 2015a). Researches are exploring ways out from the future's probable universal energy calamity which might be as a result of the whole or partial ruin of conventional energy sources and high carbon emission which are responsible for the menace of global warming, decreasing availability of fuel wood, desertification and deforestation. These environmental problems have drawn the attention of concerned leaders, scientists and engineers to the need to find alternative sources of energy for domestic and cottage industries. For an energy source to be acceptable, it should be renewable and must be accessible to the low income class of the society (Sambo, 2001). Of all the available energy resources in Nigeria, coal and coal derivatives (for instance, smokeless coal briquettes, bio-coal briquettes and biomass briquettes) have been discovered to possess the highest potential for use as a suitable alternative to coal and fuel wood in industrial boilers and brick kilns for thermal application and domestic purposes.

Combustion of coal is known to release the highest levels of pollutants such as particulates and trace elements, like mercury, etc. Unless cleaner and more efficient coal technologies are deployed, the use of coal for energy generation will worsen global environmental problems (Oyelaran et al., 2015b). Based on this fact, to ensure that the issue of pollution from coal combustion and excessive use of fuel wood are curtailed, it is of essence to find alternates for coal and fuelwood. For thermal energy application in some domestic appliances, an industrial boiler and a brick kiln, bio-briquettes have shown to possess some properties and potential for use as a suitable substitute to coal and wood fuel. Therefore, bio-briquettes will serve as the most effective method of combating deforestation and desertification in the countries where coal is cheap and readily available. Bio-coal briquettes can be prepared by compacting pulverized coal, biomass, binder and a sulphur fixation agent (Lu et al., 2000). A sulphur fixation agent known as a desulphurizing agent is added in order to ensure that most of the sulphur content of the coal is fixed into the ash instead of being liberated into the atmosphere as sulphur (iv) dioxide (Somchai et al., 1988). Kwong et al. (2004) wrote that better combustion performance and reduced pollutant emission are achieved by bio-coal briquettes during combustion. Soil treatment and enrichment effectiveness shown by ash of bio-coal briquettes is also an added advantage (Schrinding et al., 2000). In the study on the development of fuel briquettes for household and industrial purposes, Raju et al. (2014) wrote that preserving the forest resources by substituting fuel wood with bio-briquettes, and the use of the ash produced from this briquette for soil treatment will compensate for fossil carbon emitted by the coal component of the briquette. Hence, bio-coal briquettes can be considered to be a clean technology.

A large quantity of groundnut shell, a residue from groundnut, which is obtainable on farms and processing sites, has compounded the already existing waste disposal problem. For this reason, an urgent attempt must be made in upgrading its usefulness with the aim of solving some environmental problems associated with its disposal. Thus, they need to convert them to a more useful form. Greenhouse gases, which are an unpleasant and major contributor towards the environmental pollution, are emitted if raw coal is used for heating purposes (Kim and Sadakata, 2002). The problem of energy crisis can thus be addressed by harnessing the power of indigenous coal reserves through improved technology, blending, etc. The handling and burning of raw coal for domestic, light industrial and commercial applications have posed a challenging problem, which is mainly due to the coal's high ignition temperature, varying quality, ash, particle emission, and smoke generation. The search by nations to produce efficient and reliable energy for industrial and domestic uses has rekindled interest in coal and how it can be used without its harmful environmental impact and its accompanying health hazards. Some of the methods used to eliminate such problems are densification, desulphurization and blending of coal 
with biomass. It has been proved that blending coal with biomass gives rise to briquettes, which have better fuel properties and less harmful emissions compared with raw coal briquettes (Kim et al., 2002). The biomass component of briquettes which ignites at a lower temperature compared with coal, ensures that volatile matter in coal, which would otherwise be liberated as smoke, at a low combustion temperature combusts completely. The advantage of bio-coal briquetting is that any grade of coal can be used, hence, it puts a low rank coal into use. The ash formed from burning of bio-coal briquettes is rich in nutrients that can be used for both soil treatment and enrichment (Hayami et al., 2011).

A number of studies have been carried out in the past two decades on how to develop the quality of coal briquettes using a variety of methods, which included processes like carbonizing the coal prior to briquetting or addition of lime-based adsorbent $(\mathrm{CaO})$ into the coal briquettes (Mahidin et al., 2011). A 40\% reduction in $\mathrm{SO}_{2}$ from the flue gas was reported by Ren et al. (1999), when it is treated by mixing $\mathrm{CaCO}_{3}$ with the coal briquette in a $4 \mathrm{t} / \mathrm{h}$ traveling grate furnace. Naruse et al. (1998) wrote that 75$95 \% \mathrm{SO}_{2}$ emissions are reduced during the combustion of bio-briquettes. Snails live in wet vegetation and are mostly abundant in rainy seasons and are relatively more active at night (Adzor et al., 2016). The snail shells have been used as fillers in the ceramic industry, paint, animal feed, construction and paper industry for their rich source of calcium. Shell powder is known to increase the hardness of the product, resistance to weathering and strength of the material.

The use of co-fuel, especially biomass, and coal combustion, also known as co-combustion, has some benefits. Among the benefits are the reduction of gas emissions of $\mathrm{CO}_{2}, \mathrm{~N}_{2} \mathrm{O}$ and $\mathrm{NO}_{x}$ (Mahidin et al., 2013). Biomass is acknowledged as a neutral cycle energy source. However, the hazard of $\mathrm{SO}_{\mathrm{x}}$ emissions is still related with co-combustion, particularly if low-rank coal is utilized as a primary fuel. It is therefore necessary to adsorb and control $\mathrm{SO}_{x}$ emission during co-combustion. The sulphur content are fixed in ash rather than to the atmosphere. The aim of this work is to examine some characteristics of the produced briquettes as a function of their compositions (coal/ groundnut shell ratios) and $\mathrm{Ca} / \mathrm{S}$ ratios using snail shell as an adsorbent and the special consequences of the ratio of $\mathrm{Ca} / \mathrm{S}$ on the $\mathrm{SO}_{2}$ profile and efficiency of desulphurization.

\section{Methods}

The sub-bituminous coal used in this study was sourced from Onyeama mine. Groundnut shell residues were sourced from the processing sites at Dawanu, Kano. Cassava starch was bought from Ikole-Ekiti market and snail shell was sourced from dump sites around Ikole-Ekiti, all in Nigeria.

\section{Preparation of briquette samples}

The coal and the groundnut shell sample were screened of impurities like metallic objects, chips of wood and sand preparatory to milling and labeling. The shell was thoroughly washed to remove impurities and sundried for fourteen days so as obtain stable moisture content. Coal and groundnut shell were then milled and sieved by passing through a 2-mm sieve size, while snail shell was grinded to powder, and samples were then sieved using a sieve of a $63-\mu \mathrm{m}$ pore size to obtain a fine powder. The cassava starch was prepared with hot water so as to form a starch gel. Thereafter, coal, groundnut shell and snail shell were thoroughly mixed with starch gel. Twelve samples each from the blend with coal at various mixing proportions of briquettes of various groundnut shell proportions were made at various composition ratios of coal and groundnut shell by weight (100: $0,90: 10,80: 20,70: 30$, and 60:40). 10\% of cassava starch gel was used as binder. The percentage of binder is based on the mass of the mixture. The $\mathrm{Ca} / \mathrm{S}$ ratios of 1:1, 1.25:1, 1.5:1, 1.75:1 and 2:1 (in mole) were used. The desulphurizing agent in the briquette reacts with the sulphur in coal and fixes it into ash. The $\mathrm{Ca} / \mathrm{S}$ is the ratio of calcium to sulphur (Ca/S) in mole/mole.

After proper mixing, the sample was then put into the mould and pressed using machine press with a pressure of 6 ton $/ \mathrm{cm}^{2}$. After pressing, the briquette produced was removed from the mould and dried. Fig. 1 shows the steps of coal-groundnut shell preparation using snail shell as a desulphurizer.

The weighing of samples was carried out using digital weighing balance with an accuracy of $0.1 \mathrm{~g}$ and $600 \mathrm{~g}$ maximum load. Briquettes in various combinations were produced using a manually operated hydraulic briquetting machine with a dwell time of 120 seconds. The briquettes were then sundried for 14 days before study. 
Fig. 1. Steps of coal-groundnut shell preparation using snail shell as a desulphurizer.

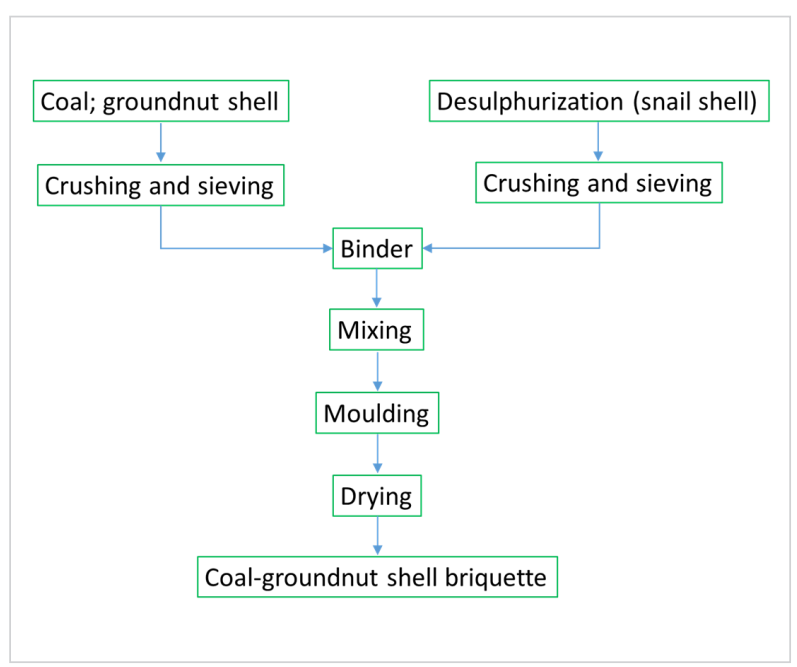

To determine briquette quality, some physical properties of briquettes such as durability, porosity and equivalent humidity content (humidity resistance) were evaluated. The $\mathrm{Ca} / \mathrm{S}$ ratios using snail shell as adsorbent, the consequences of the combustion temperature, the $\mathrm{Ca} / \mathrm{S}$ ratio on the profile of $\mathrm{SO}_{2}$ and desulphurization effectiveness were also determined.

\section{Determination of durability}

The method used by Sah et al. (1981) and Oyelaran et al. (2014) was adopted. The produced briquettes were dropped four times from a height of $1.85 \mathrm{~m}$ on a flat steel plate. The durability (\%) was calculated using Equation 1.

Durability $(\%)=$

$=\frac{\text { Mass of the material remaining on the metal plate }}{\text { Initial mass of briquette }} \times 100$

\section{Determination of porosity index}

The amount of water each briquette is able to absorb is its porosity. Porosity of the briquettes was determined by weighing each of the samples prior to immersion in water $\left(W_{a}\right)$ and weighing of the briquettes after immersing them in separate beakers containing $500 \mathrm{~mL}$ of water for 3 minutes $\left(W_{b}\right)$. The porosity index was calculated as the ratio of the mass of water absorbed by the samples to the mass of the sample before immersion.
Porosity $=\frac{W_{b}-W_{a}}{W_{a}} \times 100$

Where: $W_{a}=$ weight before test; $W_{b}=$ weight after test.

\section{Determination of equivalent humidity content}

In the equivalent humidity content (humidity resistance) test, the method used by Bilgin and Koger (2015) was adopted in this work where briquettes are kept for 21 days in a room of $20^{\circ} \mathrm{C}$ temperature and $50 \%$ humidity. The weights of briquettes prior to the test and after the test were recorded. Humidity resistance was calculated as a percentage based on weight increase during the storage.

\section{Desulphurization and desulphurization efficiency test}

The desulphurization test was carried out by adopting the method used by Mahidin et al. (2011) where a horizontal pipe furnace with an electrical heater element attached was used by placing the bio-briquette in the pipe. Desulphurization was carried out at $300^{\circ} \mathrm{C}$ and $500^{\circ} \mathrm{C}$ temperatures at an interval of $50^{\circ} \mathrm{C}$ and ratios of $\mathrm{Ca} / \mathrm{S} 1: 1,1.25: 1$, 1.50:1, 1.75:1 and 2:1. At intervals of 1, 2, 4, 6, 8, 10 and 12 minutes, the flue gas was analyzed using Gas Analyzer. The efficiency of desulphurization was calculated using the equation used by Naruse et al. (1998) and Lu et al. (1998). The desulphurization air-flow rate and time were $1.2 \mathrm{~L} / \mathrm{min}(200 \%$ excess of stoichiometric air-to-fuel ratio) and 12 minutes, respectively.

$$
\prod_{\mathrm{SO}_{2}}=\frac{S O_{(C a / S=n)}}{S O_{C a / S=0)}}
$$

Where $\mathrm{SO}_{2(\mathrm{Ca} / \mathrm{S}=0)}$ is $\mathrm{SO}_{2}$ emission without desulphurizer, and $\mathrm{SO}_{2(\mathrm{C} / \mathrm{S}=\mathrm{n})}$ is $\mathrm{SO}_{2}$ emission with a desulphurizer.

\section{Results and Discussion}

Ingrading briquette quality, its durability is essential since it foretells the briquette performance during handling, transportation and storage. The durability test result of the briquettes is shown in Fig. 2, which demonstrates that the durability ranges between 88.67 and $98.80 \%$. The highest durability of $98.80 \%$ was obtained in a briquette with a 90:10 coal-groundnut shell ratio 
and 1:1 Ca/S, while the lowest was obtained at 2:1 Ca/S and a 50:50 coal-groundnut shell ratio. Increasing the desulphurizer has no substantial effect on the durability of the briquettes; however, a close look at the results enthusiastically discloses that increase in groundnut shell has considerable consequences on durability of the briquettes. It can be seen from the graph that briquettes with up to $40 \%$ of groundnut shell in the admixture have durability above $90 \%$. For this reason, a stable briquette can be made of coal and up to $40 \%$ groundnut shell admixtures. The result discloses that higher biomass content in coal briquette lowers its durability. This is in agreement with Kaliyan and Morey (2009), who wrote that durability of briquettes was strongly related to forces that bond coal and biomass particles together. The values obtained are comparatively higher than those reported by Wamukonya and Jenkins (1995), which were in the range of 46.5 and $88.4 \%$, achieved for sawdust and wheat straw briquettes. Fines of up to $5 \%$ (by weight) were suggested by Karunanithy et al. (2011) as the acceptable level, and greater than $5 \%$ will result in reducing storage capacity, and hitches in flow characteristics might be created. Tabil and Sokhansanj (1996) categorize the durability into high (>0.8), medium (0.7-0.8) and low (<0.7) based on the values. The briquettes produced using both standards showed that all the briquettes tested had high durability.

The porosity index of the briquettes as shown in Fig. 3 increased as the percentage of biomass increased, with
$50 \%$ groundnut shell with a 2:1 $\mathrm{Ca} / \mathrm{S}$ desulphurization ratio having the highest value of 0.41 . This is because the groundnut shell particles are fibrous, and not as fine as coal particles. Hence, as the percentage of biomass in the coal briquette increases, the number of air spaces where water molecules stick on to the briquettes increases thereby causing an increase in the volume of water the briquettes absorbed. This then results in an increase in the weight of the sample immersed in water. The coal-groundnut shell 90:10 ratio briquette has the lowest porosity index value of 0.19 with a $1: 1 \mathrm{Ca} / \mathrm{S}$ desulphurization ratio. This is due to the fact that the particles are tightly packed together and less volume of water was absorbed. Note that low porosity hampers mass transfer in combustion owing to lesser spaces for mass diffusion. The rates of infiltration of oxidant and outflow of combustion and pyrolysis products during combustion increase with higher porosity and result in a higher burning rate (Onuegbu et al., 2010). The results of the water resistance obtained supported the earlier results obtained in the durability measurement, which shows that the briquette with highest coal in the coal-groundnut shell briquette provided the strongest bio-briquettes. Therefore, the effect of $\mathrm{Ca} / \mathrm{S}$ became evident; the lowest $\mathrm{Ca} / \mathrm{S}$ ratio provided the strongest bio-briquette.

Fig. 4 shows the results of the humidity resistance of the produced briquettes. The highest resistance to humidity of $99.40 \%$ was achieved at a 90:10 coal-groundnut shell ratio and a 1:1 $\mathrm{Ca} / \mathrm{S}$ ratio, while the least resistance

Fig. 2. Result of durability test of bio-briquettes

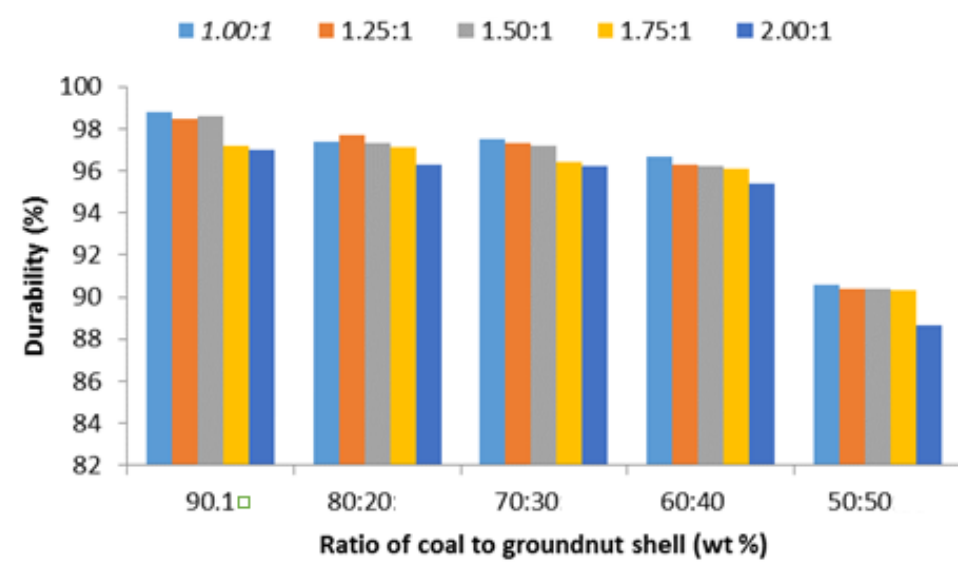


Fig. 3. Result of porosity index of bio-briquettes

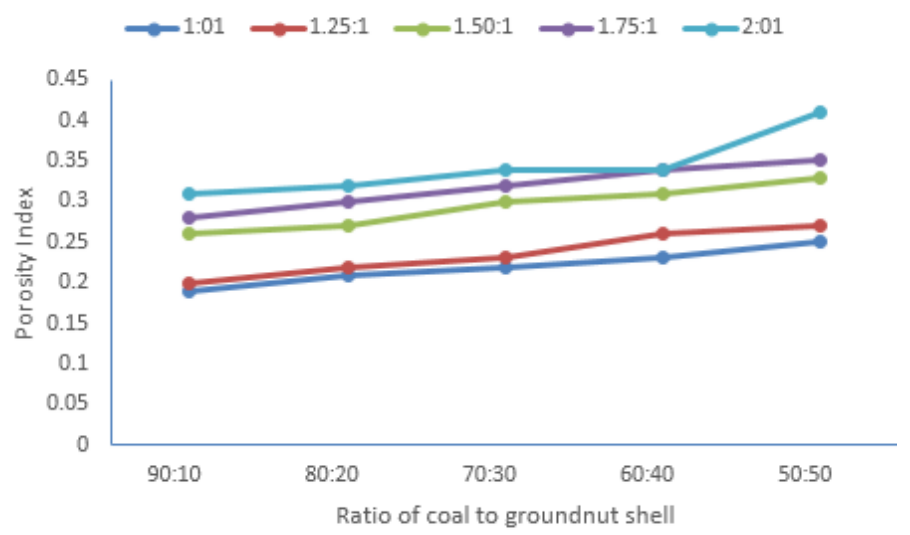

Fig. 4. Result of humidity resistance of bio-briquettes

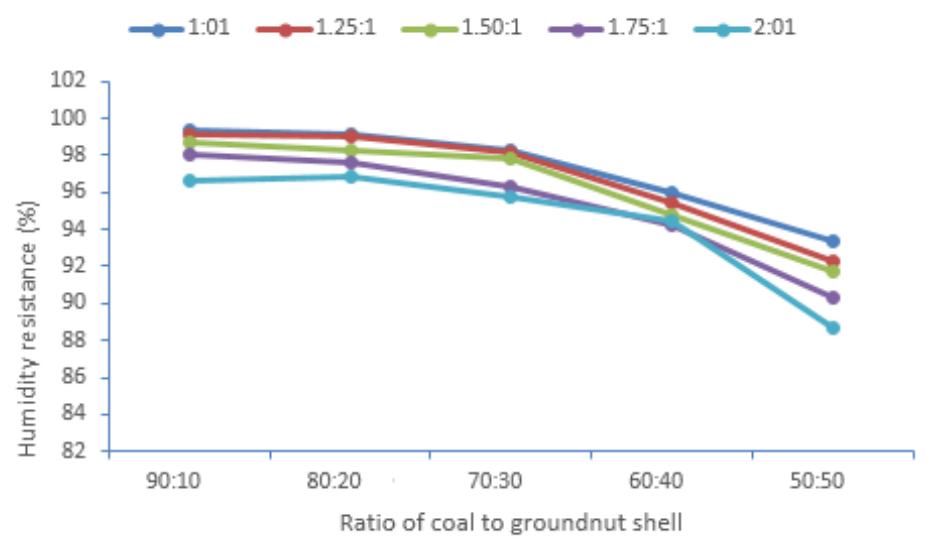

of $88.71 \%$ was recorded in a $50: 50$ ratio briquette composition with a $2: 1 \mathrm{Ca} / \mathrm{S}$ ratio. From the results obtained, it shows that humidity resistance decreases as the groundnut shell content increases. This observable fact might be due to the result of the cellulosic nature of groundnut shell which was relatively higher than that of coal. The figure also shows that humidity resistance decreases with increase in the adsorbent. From the results acquired, coal, which is a major environmental pollutant when combusted, can be utilized effectively with up to $40 \%$ biomass and a lower $\mathrm{Ca} / \mathrm{S}$ desulphurization ratio as a solid biofuel for boilers and household usage.

\section{Effect of temperature on the $\mathrm{SO}_{2}$ profile without adsorbent}

The aim of this test is to establish the consequences of temperature on coal-groundnut shell briquette combustion without the use of adsorbent. The result obtained is used as a point of reference in estimating the efficiency of desulphurization of a bio-briquette when adsorbent was introduced in a bio-briquette. The $\mathrm{SO}_{2}$ profiles produced in combustion without adsorbents in bio-briquette are shown in Fig. 5. The highest concentration of $\mathrm{SO}_{2}$ was recorded at a combustion temperature of $500^{\circ} \mathrm{C}$. It is apparent from the result obtained that the amount of 
$\mathrm{SO}_{2}$ released in the flue gas is affected by the combustion temperature and this trend was observed at all temperatures studied. After 1 minute of burning, the highest concentration of $45 \mathrm{ppm} \mathrm{SO}_{2}$ was obtained at $500^{\circ} \mathrm{C}$ and the lowest of $17 \mathrm{ppm}$ at $300^{\circ} \mathrm{C}$. However, after burning for 12 minutes, there is a drop-in concentration of the released $\mathrm{SO}_{2}$ to $25 \mathrm{ppm}$ and $9 \mathrm{ppm}$ at $500^{\circ} \mathrm{C}$ and $300^{\circ} \mathrm{C}$, respectively.

Fig. 5. $\mathrm{SO}_{2}$ profile in flue gas during the ${ }^{*} 8 \mathrm{combustion}$ of bio-briquettes without adsorbent

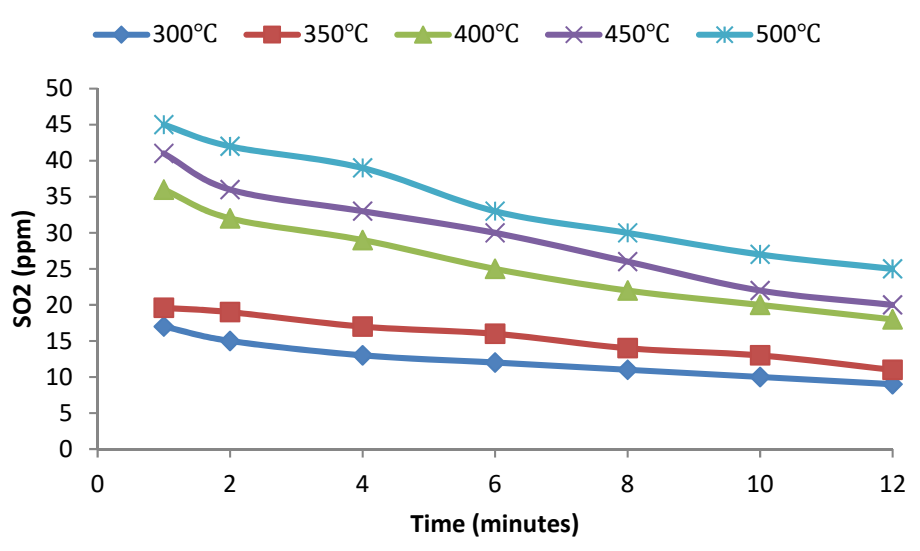

\section{Effect of $\mathrm{Ca} / \mathrm{S}$ ratio and temperature on the $\mathrm{SO}_{2}$ profile with adsorbent}

The profile of $\mathrm{SO}_{2}$ as the function of temperature and the $\mathrm{Ca} / \mathrm{S}$ ratio during burning of the bio-briquette samples are shown in Figs. 6 to 10. The figures reveal that the $\mathrm{SO}_{2}$ content in the flue gas was significantly reduced to a lower level, particularly at the higher $\mathrm{Ca} / \mathrm{S}$ ratio and temperature. The lowest $\mathrm{SO}_{2}$ of $1.04 \mathrm{ppm}$ was detected at $500^{\circ} \mathrm{C}$ and a $2: 1 \mathrm{Ca} / \mathrm{S}$ ratio, and the highest of 14.95 ppm was detected at a 1:1 Ca/S ratio and $300^{\circ} \mathrm{C}$. The results reveal that the $\mathrm{SO}_{2}$ concentration decreases with an increase in temperature and the $\mathrm{Ca} / \mathrm{S}$ ratio. From the result obtained for better desulphurization, the 2:1 $\mathrm{Ca} / \mathrm{S}$ ratio is recommended. This is in agreement with Mahidin et al. (2011) who wrote that the highest $\mathrm{SO}_{2}$ inhibition in bio-briquette combustion occurred at a 2:1 $\mathrm{Ca} / \mathrm{S}$ ratio. Similar results were also obtained in coal combustion at a $\mathrm{Ca} / \mathrm{S}$ ratio of 2:1 for coal combustion (Tabil and Sokhansanj, 1996). The snail shell that is not calcine has a Ca content of $23.11 \%$ (wt) (Energy Group, 2016), which is considerably lower than $53 \%$ for limestone as reported by Naruse et al. (1998). Nevertheless, snail shell was found to exhibit good desulphurization abilities as a result of $\mathrm{CaO}$ content and higher porosity after calcination as explained by Mahidin et al. (2011).

After 12 minutes of running the experiment, the amount of $\mathrm{SO}_{2}$ released declined sharply for each $\mathrm{Ca} / \mathrm{S}$ ratios as seen in Figs. 6 to 10. It can therefore be right to conclude that the adsorbent was able to shift the $\mathrm{SO}_{2}$ emissions. Furthermore, an increase in temperature has a tendency of lowering the $\mathrm{SO}_{2}$ production, though the effect was not considerable. This clarifies the reason why the calcination of the snail shell gets better at the higher temperature of $500^{\circ} \mathrm{C}$, since a much higher amount of $\mathrm{CaO}$ is formed. The results obtained in this work support the previous observation (Lu et al., 2000; Wang et al., 2000). Furthermore, the advantage of this adsorbent is that the desulphurization/calcination temperatures were lower $\left(<500^{\circ} \mathrm{C}\right)$ compared with another adsorbent, for example, limestone $\left(>800^{\circ} \mathrm{C}\right)$ and scallop shell $\left(>625^{\circ} \mathrm{C}\right)$.

Fig. 11 clearly demonstrates that the efficiency of desulphurization increases by increasing the temperature of combustion and the $\mathrm{Ca} / \mathrm{S}$ ratio. As shown, the consequence of temperature was more apparent than that of the $\mathrm{Ca} / \mathrm{S}$ ratio. The maximum efficiency attained is $89.3 \%$, at $500^{\circ} \mathrm{C}$ and a $2: 1 \mathrm{Ca} / \mathrm{S}$ ratio. The efficiency obtained is 
Fig. 6. $\mathrm{SO}_{2}$ profile in flue gas at $300{ }^{\circ} \mathrm{C}$ during the combustion of bio-briquettes

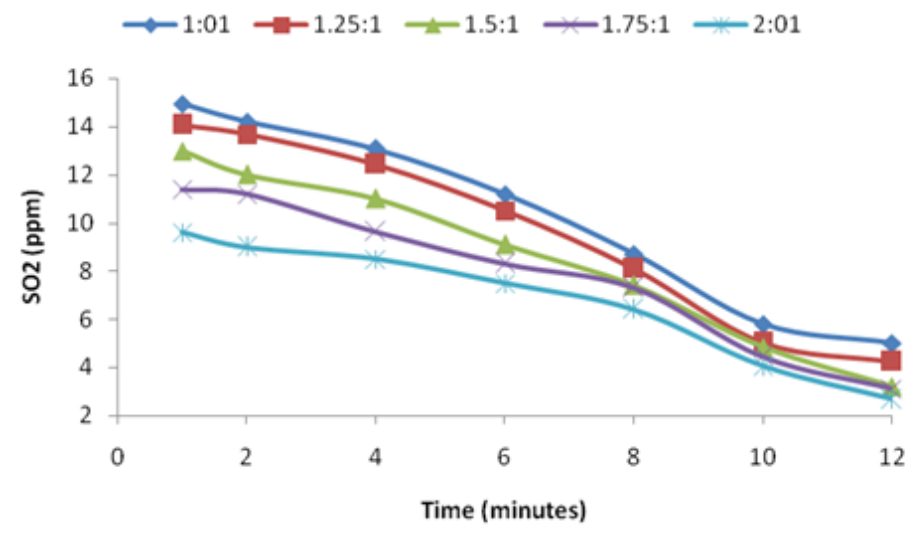

Fig. $7 \mathrm{SO}_{2}$ profile in flue gas at 350during the combustion of bio-briquettes

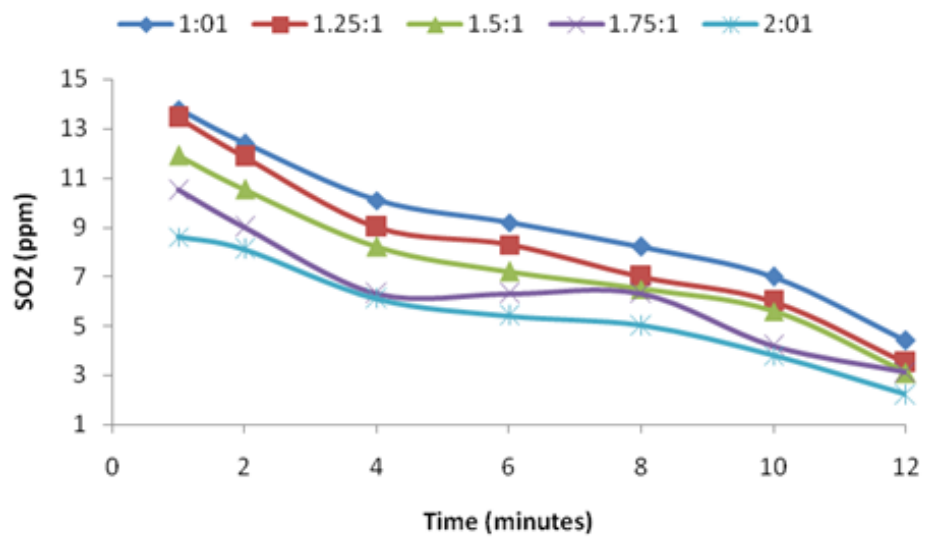

Fig. $8 \mathrm{SO}_{2}$ profile in flue gas at $400^{\circ} \mathrm{C}$ during the combustion of bio-briquettes

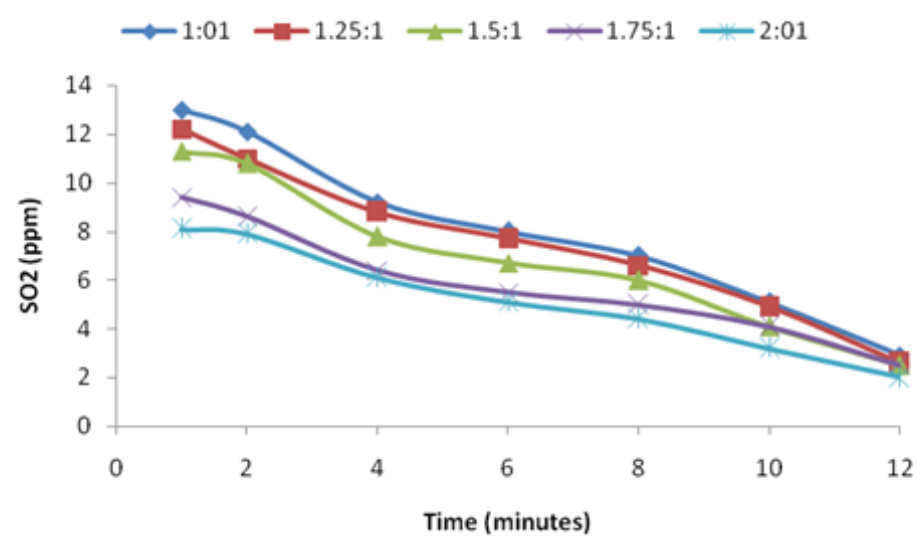


Fig. $9 \mathrm{SO}_{2}$ pOrofile in flue gas at $450^{\circ} \mathrm{C}$ during the combustion of bio-briquettes

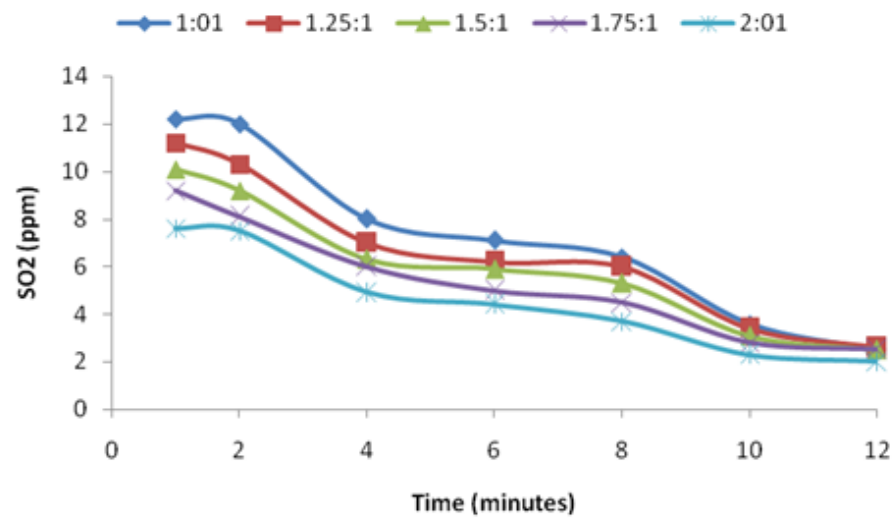

Fig. $10 \mathrm{SO}_{2}$ profile in flue gas at $500^{\circ} \mathrm{C}$ during the combustion of bio-briquettes

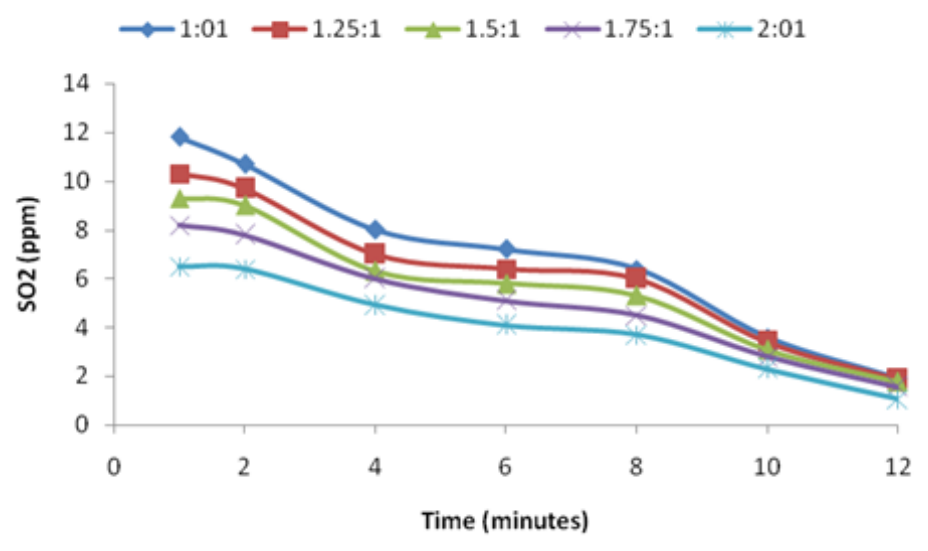

Fig. 11 Desulphurization efficiency as a function of temperature and Ca/S ratio

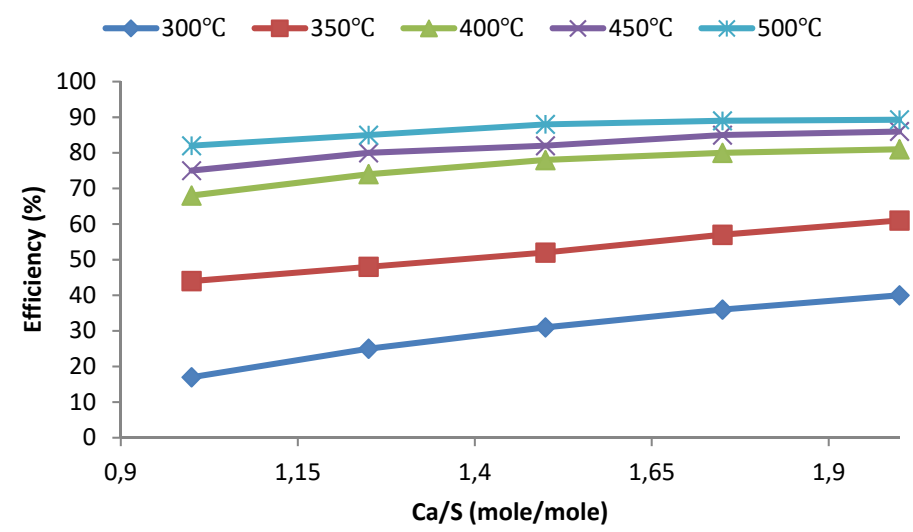


significantly higher than that reported by Lu et al. (2000), which was $67 \%$, and relatively higher compared with $80 \%$ by Naruse et al. (1998) and by Mahidin et al. (2011). The result is comparable with that reported by Wang et al. (2000) who obtained 75-95\% when slaked lime was used in the combustion of bio-briquettes.

In their studies, Naruse et al. (1998) and Lu et al. (1998) used a temperature range $\left(700-900^{\circ} \mathrm{C}\right)$ which is higher in addition to $\mathrm{Ca} / \mathrm{S}$ ratios up to 5 with only $80 \%$ as the highest efficiency. These studies claimed that scallop shell had a calcination temperature of about $627^{\circ} \mathrm{C}$. Nevertheless, it is likely that the calcination temperature of scallop shells is actually lower than $600^{\circ} \mathrm{C}$ because the desulphurization efficiency obtained in this study is greater than any reported in the past. As stated earlier, this research was carried out at temperatures $\leq 500^{\circ} \mathrm{C}$. All the results obtained in this study concerning desulphurization efficiency are in agreement with proofs witnessed in the past (Naruse et al., 1998; Lu et al., 2000), to be precise those showing that the desulphurization efficiency tends to increase with the $\mathrm{Ca} / \mathrm{S}$ ratio. With the temperature and the $\mathrm{Ca} / \mathrm{S}$ ratio significantly influencing some data but at higher temperatures, the effect of the $\mathrm{Ca} / \mathrm{S}$ ratio is not strong enough.

\section{References}

Adapa P, Tabil L, Schoenau G. (2009) Compaction characteristics of barley, canola, oat and wheat straw. Biosystems Engineering. 104(3):335-344. https://doi.org/10.1016/j.biosystemseng.2009.06.022

Bolaji B.O. (2005) The use of Sawdust as an alternative source of energy for domestic cooking and as a means of reducing deforestation. Global Journal of Environmental Sciences. 4(1): 73-76. https://doi.org/10.4314/gjes.v4i1.2444

Adzor S.A, Nwoke V.U. Akaluzia R.O. (2016) Investigation of the Suitability of Periwinkle Snail Shells as Carburizing Material for the Surface Hardness Improvement of Low Carbon Steel. European Journal of Material Sciences. 3(2):13-23.

Bilgin H. Y, Koger A. (2015) Briquetting of greenhouse pepper crop residues, Agricultural Engineering International, CIGR Journal Special issue. 185 - 192.

Energy group Department of Mechanical Engineering, Report Unpublished, 2016.

Hayami H, Wake Y, Kojimaand T, Yoshioka K. (2001) Bio-coal Briquettes and Planting Trees As An Experimental CDM in China. Keio Economic Observatory Discussion Paper. 136: 1-20,

\section{Conclusions}

The $\mathrm{SO}_{2}$ emissions from bio-briquettes was effectively inhibited by introducing adsorbent into bio-briquettes during combustion. Snail shell adsorbent was substantiated to have self-desulphurization abilities in bio-briquette combustion. Desulphurization primarily occurred during the devolatilization and char combustion stages as the $\mathrm{SO}_{2}$ was also captured at lower temperature $\left(300^{\circ} \mathrm{C}\right)$. It was observed in this study that the bio-briquettes with $90 \%$ coal and the 1:1 Ca/S ratio possess the best quality that can be used for household and cottage industries as shown in the results. The bio-briquettes with $90 \%$ of coal have better water resistance; hence, they will not be easily affected by their exposure to moist air and water when stored or transported. The results obtained also reveal that bio-briquettes with higher $\mathrm{Ca} / \mathrm{S}$ are easily devastated and dissolved since their structures are weak. The result also shows that snail shell can be used as a desulphurizer in coal-biomass briquetting where the sulphur content is fixed in ash rather than to the atmosphere.

Kaliyan N, Morey R.V. (2009) Factors Affecting Strength and Durability of Densified Biomass Products. Biomass and Bioenergy. 33(3): 337-359. https://doi.org/10.1016/j.biombioe.2008.08.005 Karunanithy C, Wang Y, Muthukumarappan K, Pugalenghi S. (2011) Physiochemical characterization of briquettes made from different feedstock. Biotechnology Research International. ID 165202: 1-9. https://doi.org/10.1155/2012/165202

Kim H. (2003) Utilization of Biomass for Homeostasis Engineering, Binding and Desulphurization Characteristics Of Pulp Black Liquor in Bio-coal Briquettes. Department of Ecological Engineering, Toyohashi, Japan. 1-2.

Kim H, Lu G, Li T, Sadakata M. (2002) Binding and Desulphurization Characteristics of Pulp Black Liquor in Biocoal Briquettes. Environment Science and Technology. 36(7):16071612, https://doi.org/10.1021/es0105921

Kim H, Sadakata M. (2002) Binding and desulphurization characteristics of pulp black liquor in biocoal briquettes. Environmental Science Technology 36: 160-712. https://doi.org/10.1021/es0105921

Kwong P.C, Wang J, Chao C, Cheung C, Kendall G. (2004) Effect of co-combustion of coal and rice husk on the combustion 
performance and pollutant emission. In proceeding of the 7th Asia Pacific Symposium on Combustion and Energy Utilization. Asia: 1 -6.

Lu G, Wang Q, Sakamoto K, Kim H., Naruse I, Yuan J, Maruyama T, Kamide M, Sadakata M. (2000) Experimental study on combustion and pollutant control of biobriquette. Energy and Fuels. 14(6): 1133-1138. https://doi.org/10.1021/ef990115s

Lu G, Kim H, Yuan J, Naruse I, Ohtake K, Kamide M. (1998) Experimental Study on Self-desulfurization Characteristics of Biobriquettein Combustion. Energy and Fuels.12(4): 689-696. https://doi.org/10.1021/ef970194c

Mahidin M, Gani A, Khairil A. (2011) Physical Characterization and Desulfurization of Biobriquette Using Calcium-Based Adsorbent. Makara, Journal of Teknologi. 15(2): 178-182.https:// doi.org/10.7454/mst.v15i2.937

Mahidin, Syamsuddin, Y. \& Rizal, S., (2013) Use of Biomass as Co-fuel in Briquetting of Low-rank coal: Strengthen the Energy Supply and Save the Environment, International Journal of Chemical, Nuclear, Metallurgicaland Materials Engineering.7(12): 643-648.

Naruse I, Kim H, Lu G, Yuan J, Ohtake K. (1998) Study onCharacteristics of Self-desulfurization and Self-denitrification in Biobriquette combustion. Symposium (International) on Combustion. 27(2): 2973-2979. https://doi.org/10.1016/S00820784(98)80157-4

Onuegbu T. U, Ogbu I M, Ilochi N. O, Ekpunobi U. E, Ogbuagu A. S. (2010) Enhancing the Properties of Coal Briquette using Spear Grass. Leonardo Journal of Science. 9(17):47-58.

Oyelaran O. A, Bolaji B. O, Waheed M. A, Adekunle M. F. (2015a) Characterization of Briquettes Produced from Groundnut Shell and Waste Paper Admixture. Iranica Journal of Energy and Environment 6(1): 34-38. https://doi.org/10.5829/idosi. ijee.2015.06.01.07

Oyelaran O. A, Tudunwada Y. Y. (2015b,) Determination of the Bioenergy Potential of Melon Shell and Corn Cob Briquette. Iranica Journal of Energy and Environment. 6(3): 167-172. https://doi.org/10.5829/idosi.ijee.2015.06.03.03

Oyelaran O. A, Bolaji B. O, Waheed M. A, Adekunle M. F. (2014) Effects of Binding Ratios on Some Densification Characteristics of Groundnut Shell Briquette. Iranica Journal of Energy and Environment. 5(2): 167-172. https://doi.org/10.5829/idosi. ijee.2014.05.02.08
Patomsok W. (2008) Density equation of biocoal briquette and quality of maize cob in Thailand. American Journal of Applied Science. 5(12): 1808-1811. https://doi.org/10.3844/ ajassp.2008.1808.1811

Raju C. A, Jyothi K. R, Satya M, Praveena U. (2014) Studies on development of fuel briquettes for household and industrial purpose. International Journal of Research in Engineering and Technology. 3(2): 54-63. https://doi.org/10.15623/ ijret.2014.0302011

Ren Y.Z, Dong J.F, Cao Y.Q, Qian J.Q. (1999) A New Technology onlncreasing Desulfurization Property of Clean Briquette.J. Eng. Thermophysics20(1): 125-128.

Sah P, Singh B. and U. Agarwal, (1981) Compaction behaviour of straw",Journal of Agricultural Engineering. 18(1):89-96. https:// doi.org/10.1016/0013-7952(81)90049-1

Sambo A. S. (2001) Renewable energy technologies for national development: status,prospects and policy directions. The Nigerian Engineers.

Von Schirnding Y, Bruce N, Smith K, Ballard-Tremmer G, Ezzati M, Lvovschy K. (2010) Addressing the impact of household energy and indoor air pollution on the health of the poor: Implication for policy action and intervention measures, WHO, Washington D.C.

Somchai O, Kunchana B, Duangporn T. (1988) In-situ Desulfurization of Coal Briquettes by Lime. Department of Chemical Technology, Chulalondkorn University, Bangkok, Thailand. 1 -20.

Tabil L. Jr, Sokhansanj S. Process conditions affecting the physical quality of alfalfa pellets. Applied Engineering in Agriculture 1996, 12(3):345-350.https://doi.org/10.13031/2013.25658

Wamukonya L, Jenkins B. (1995) Durability and relaxation of sawdust and wheat-straw briquettes as possible fuels for Kenya. Biomass and Bioenergy. 8(3): 175-179.https://doi. org/10.1016/0961-9534(95)00016-Z

Wang Q, Lu G, Sakamoto K, Maruyama T, Kim H, Naruse I, Hatakema S, Mizoguchi T, Luo, M. Kamide R. (2000) Studies on combustion and sulphur fixation characteristics of coal-biomass briquette. EarozoruKenkyu. 15: 364-371 (in Japan with English abstract),

Yaman M, Sahan M, Haykiri-Açma H, Sesen K, Küçükbayrak S. (2001) Fuel briquettes from biomass-lignite blends. Fuel ProcessingTechnology.72: 1-8,. https://doi.org/10.1016/S03783820(01)00170-9 